\title{
PELATIHAN KERAJINAN PEMBUATAN TAS DARI TALI KUR BAGI IBU PERSIT KARTIKA CANDRA KIRANA KOMPI MARKAS 432 KOSTRAD KARIANGO KABUPATEN MAROS
}

\author{
Amirah Mawardi, Sitti Satriani, Sumiati dan Mutmainnah ${ }^{1}$ \\ ${ }^{1}$ Universitas Muhammadiyah Makassar \\ e-mail: amirahmawardi@yahoo.co.id
}

\begin{abstract}
Abstrak
Program Pengabdian Kepada Masyarakat dilaksanakan di kompleks militer di daerah Kariango, Kabupaten Maros, Sulawesi Selatan yang dikenal dengan Komando Strategi Angkatan Darat (Kostrad) Kariango. Namun pada IbM ini kami hanya fokus pada satu kompi yaitu kompi Markas yang ada di Batalion 432 Kostrad Kariango dalam memberikan pelatihan kerajinan tangan kepada ibu-ibu yang tidak memiliki aktifitas selain menjadi ibu rumah tangga dan menjadi ibu Persit yang memliki rutinitas setiap hari melayani kebutuhan suami dan anak serta sibuk mengikuti kegiatan olah raga, seni dan budaya yang ditentukan oleh pengurus persit yang ada di Kostrad Kariango. Kondisi yang telah lama terjadi di kalangan ibu-ibu persit kostrad kariango a). Rutinitas yang hampir setiap hari sama, membuat ibu persit yang tidak memiliki aktifitas di luar asrama membutuhkan kegiatan lain. b). Kerajinan tangan seperti tas yang terbuat dari Tali Kur merupakan kerajinan yang bernilai postif dan dapat menghilangkan kejenuhan dari rutinitas yang flet. c). Banyaknya ibu persit yang menginginkan memiliki penghasilan sendiri dan tetap berada di rumah sebagai ibu rumah tangga yang baik untuk suami dan anaknya namun bingung bagaimana cara memulainya sehingga mereka sangat memerlukan pelatihan membuat kerajinan tangan yang bernilai ekonomi. (home industri). d). Keberadaan ilmu manajemen pemasaran produk sangat dibutuhkan. e). Dibutuhkan motivasi untuk menumbuhkan jiwa kreativitas dan inovasi untuk ibu-ibu persit. Solusi dari permasalahan tersebut diantaranya adalah melakukan penyuluhan dan sosialisasi yang intens untuk meningkatkan pengetahuan dan keterampilan ibu-ibu persit dalam memproduksi tas dari tali kur dan perlunya di buat manajemen organisasi yang baik kepada ibu-ibu persit sebagai kelompok pembuat tas tali kur. Target luarannya a d a la h menumbuhkan jiwa kreativitas dan inovasi untuk ibu-ibu Persit kompi Markas yang ada di Batalion 432 Kostrad Kariango dan untuk mengintensifkan kembali anggota kelompok yang kurang aktif, serta sebagai upaya menarik simpati ibu persit yang lain untuk berpartisipasi dalam mengembangkan kerajinan tas dari tali kur.
\end{abstract}

Kata Kunci: Pelatihan, Tali kur, Ibu Persit

\section{A. Pendahuluan}

Istilah tali kur sebenarnya telah dikenal oleh dunia dari abad ke 13, tetapi istilah tali kur ini dikenal dengan nama Macrame yang berasal dari Timur Tengah. Pada awalnya kerajinan Macrame dibuat dari simpul-simpul di tepi kain dengan menggunakan keahlian 
tangan. Pelatihan pembuatan tas dari tali tali kur ini bertujuan untuk pengembangan diri ibuibu persit kompi Markas yang ada di Batalion 432 Kostrad Kariango dalam menyalurkan minat, bakat serta kemampuan merajut dari tali ke tali hingga membentuk sebuah benda yang dapat menjadi handuk, gantungan kunci, gelang, dan masih banyak lagi namun pada IbM ini difokuskan pada pelatihan pembuatan tas dari tali kur. Hal yang penting diketahui bahwa seni kerajinan menggunakan tali sebagai bahan dasarnya adalah merupakan salah satu cabang seni rupa terapan. Pembuatan tas dari tali kur ini bahan utama adalah tali kur, selain harganya yang relatif murah tali kur juga mudah untuk didapatkan. Pengerjaan 1(satu) tas tali kur membutuhkan waktu kurang lebih 2 hari. Setelah dianyam, tali kur bisa dipadupadankan dengan rantai ataupun dengan tali yang lain warnanya, sehingga menambah tingkat keindahan dan meningkatkan harga jual. Tidak dapat dipungkiri bahwa minat masyarakat terhadap tas dari tali kur sangat meningkat dari hari ke hari, karena tas dari tali kur ini juga memiliki model dan berbagai macam bentuk sesuai selera dan sangat mengikuti zaman. Kualitas Tali kur kuat, tidak mudah rusak, warna awet, selalu terihat baru dari masa ke masa, sehingga Pemasaran tas tali kur ini sangat mudah untuk diperjual belikan, bisa dititipkan ke toko-toko maupun dijual sendiri baik secara offline maupun online.

Berbicara rutinitas kegiatan ibu rumah tangga yang ada di Markas Kompi Batalion 432 Kostrad Kariango, hampir setiap hari rutinitas kegiatan mereka sangatlah menjemukan. Dapat dibayangkan tiap hari selama berbulan-bulan bahkan bertahun-tahun kegiatan mereka kebanyakan "flat" itu-itu saja, kejenuhan yang senantiasa mereka rasakan dalam menjalani hari-harinya. Terlebih ibu-ibu yang pernah melakukan aktifitas di luar rumah tiba-tiba berhenti dari rutinitas untuk fokus mengurus Rumah Tangga merupakan Perubahan yang signifikan, ditambah lagi jika suami mereka berangkat tugas yang bagi ibu persit adalah cobaan terbesar ketika harus menerima dengan ikhlas suami berangkat tugas dan ibu persit wajib tetap tinggal di asrama tanpa suami dengan pengawasan yang sangat ketat yaitu diharuskannya setiap ibu persit wajib lapor ketika ingin keluar asrama adalah hal tidak mudah untuk dijalani tapi harus dijalani, kata pepatah hanya wanita kuat yang bisa jadi ibu persit, Hal ini yang mendorong tim melakukakan IbM yaitu memberikan pelatihan kepada ibu-ibu persit sehingga mereka memiliki kesibukan, menghilangkan rasa jenuh dari menjalani hari-hari yang monoton, tentunya sangat bernilai positif dan ekonomis. Apabila ibu-ibu persit menekuni pelatihan pembuatan tas dari tali kur ini, suatu saat sangat berpeluang 
dijadikan lahan bisnis, karena banyak diminati masyarakat dan tentunya memiliki nilai jual yang tinggi.

Melalui kegiatan pelatihan ini, sangat besar harapan dapat meningkatkan keterampilan dan membuka lapangan kerja bagi ibu-ibu rumah tangga di Kompi Markas Kostrad Kariango sehingga bisa tercipta peluang usaha mandiri yang bergerak di sektor industri rumah tangga termasuk ikut meningkatkan daya kreativitas dalam berkarya serta inovasi ibu-ibu rumah tangga dalam berekspresi yang selanjutnya bisa menemukan hasil karya yang bermanfaat dan tepat guna. Karena pada hakekatnya sebagian besar ibu persit memiliki totalitas pengabdian sebagai ibu ruamh tangga, dengan prinsip segala dinamika tugasnya sebagi ibu persit harus menjadikan kepentingan Negara di atas kepentingan pribadi. Ini Adalah penrjanjian di atas kertas yang bermaterei yang harus di tandatangani ketika siap menjadi ibu persit. Harapan besar dengan pelatihan ini tentunya dapat memberikan pengetahuan baru, kesibukan baru yang positif, bahkan jika dimaksimalkan, hasil dari pelatihan tersebuat dapat memberikan nilai ekonomis yang tinggi bagi ibu-ibu Persit Kompi Markas 432 Kariango Kabupaten Maros.

\section{B. Masalah}

Berdasarkan latar belakang dan analisis situasi di atas, identifikasi masalah mitra antara lain:

1. Rutinitas yang hampir setiap hari sama, membuat ibu persit yang tidak memiliki aktifitas diluar asrama, sehingga membutuhkan kegiatan lain.

2. Kerajinan tangan seperti tas yang terbuat dari tali kur merupakan kerajinan yang bernilai postif dan sangat bisa menghilangkan jenuh dari rutinitas yang monoton.

3. Banyaknya ibu persit yang menginginkan memiliki penghasilan sendiri dan tetap berada di rumah sebagai ibu rumah tangga yang baik untuk suami dan anaknya namun bingung bagaimana cara memulainya sehingga mereka sangat memerlukan pelatihan membuat kerajinan tangan yang bernilai ekonomis. (home industri).

4. Keberadaan ilmu manajemen pemasaran produk sangat dibutuhkan.

5. Membutuhkan Motivasi untuk menumbuhkan jiwa kreativitas dan inovasi untuk ibu-ibu persit. 


\section{Metode Pelaksanaan}

Berdasarkan beberapa permasalahan mitra yang telah dirumuskan sebelumnya maka pendekatan yang ditawarkan untuk merealisasikan program IBM ini adalah program pemberdayaan dengan langkah-langkah sebagai berikut: 1) Tahap Persiapan; 2) Tahap Assesment; 3) Tahap Perencanaan Alternatif Kegiatan; 4) Tahap Formulasi, Rencana Aksi; 5) Tahap Pelaksanaan Kegiatan; 6) Tahap Evaluasi; serta 7) Tahap Terminasi. (Isbandi, 2008).

Program IBM ini dilaksanakan sebagai bentuk usaha program pemberdayaan, pelatihan, kepada ibu persit untuk dapat membuat tas yang terbuat dari tali kur, tidak hanya berdaya guna untuk kebutuhan pribadi saja tapi bagaimana mampu memproduksi tas dari tali kur sebanyak-banyaknya agar dapat bernilai ekonomi, kewirausahaan yang menitik beratkan kepada pengembangan usaha. Metode pelaksanaan program yang akan dilakukan adalah: 1) Pelatihan Manajemen Organisasi (Hardin, 2019: 32); 2) Pelatihan Produksi; 3) Pendampingan. Semua metode ini merupakan satu kesatuan.

\section{Pembahasan}

\section{Persiapan}

Pendekatan yang dilakukan bersifat "Bottom up", dimana perencanaan tindakan diupayakan untuk menjawab permasalahan dan kebutuhan kelompok ibu Persit Kompi Markas 432 Kariango Kabupaten Maros. Secara umum adalah sebagai berikut:

1) Identifikasi potensi

Pelaksana bersama mitra mengidentifikasi potensi yang dimiliki, yaitu jumlah peserta, ahli pembuat tas dari tali kur yang akan didatangkan, keahlian dasar para peserta, ketersediaan bahan baku, peralatan, lokasi dan tempat, manajemen, pasar maupun lingkungan Internal lainnya serta lingkungan Eksternal yang terkait kegiatan pelatihan.

2) Analisis kebutuhan. Menganalisis kebutuhan kelompok pengrajin untuk mencari solusi dari permasalahan. Memprioritaskan kebutuhan kelompok yang paling mendesak disesuaikan dengan kemampuan kelompok pengrajin.

3) Rencana Kerja

Setelah Menganalisis kebutuhan kelompok, pelaksana membuat rencana kerja atau kegiatan yang akan diterapkan. Rencana kerja meliputi: persiapan kegiatan dan pelaksanaan. 
4) Pelatihan yang meliputi dua kegiatan, yaitu : Kegiatan pelatihan manajemen organisasi meliputi:

a) Mitra lebih awal menjelaskan tentang pelaksanaan teknis dan tujuan diadakannya pelatihan dan pelaksanaan IBM tersebut.

b) Mitra diberikan motivasi bagaimana tercipta peluang usaha mandiri yang bergerak di sektor home industri yang mengacu pada bidang accessories tas.

c) Meningkatkan kreatifitas karya dan inovasi ibu Persit Kompi Markas 432 Kariango Kabupaten Maros. dalam rangka bereksperimen dan menemukan hasil karya yang bermanfaat dan tepat guna.

d) Mitra diperkenalkan tentang manajemen usaha kecil. Di dalamnya di jelaskan tentang aspek pemasaran,aspek produksi, aspek permodalan dan keuangan, dan aspek sumber daya manusia.

e) Menggali kebutuhan utama kelompok, berkaitan dengan bahan baku, proses, hingga pemasaran produk.

f) Mengadakan kursus singkat pelatihan Pembuatan Tas dari Tali Kur menjadi produk yang siap dipasarkan serta mempersiapkan medianya.

g) Melaksanakan pelatihan dan pendampingan proses produksi kepada kelompok mitra.

h) Kegiatan pelatihan perluasan jaringan pemasaran dan pemodalan,meliputi, Mengidentifikasi jaringan pasar yang telah dimiliki oleh kelompok dan menetapkan wilayah pasar potensial

i) Mendesain produk kreatif yang lebih bervariasi.

j) Melakukan temu stakeholder untuk akses permodalan.

k) Pelatihan Penyusunan proposal pendanaan,

1) Monitoring dan evaluasi untuk semua program kegiatan dan mengevaluasinya sesuai target luaran.

Berikut beberapa contoh Tas yang terbuat dari tali kur yang diberikan pelatihan cara membuatnya kepada ibu-ibu Persit Kartika Candra Kirana Kostrad 432 Kariango Kab. Maros. 


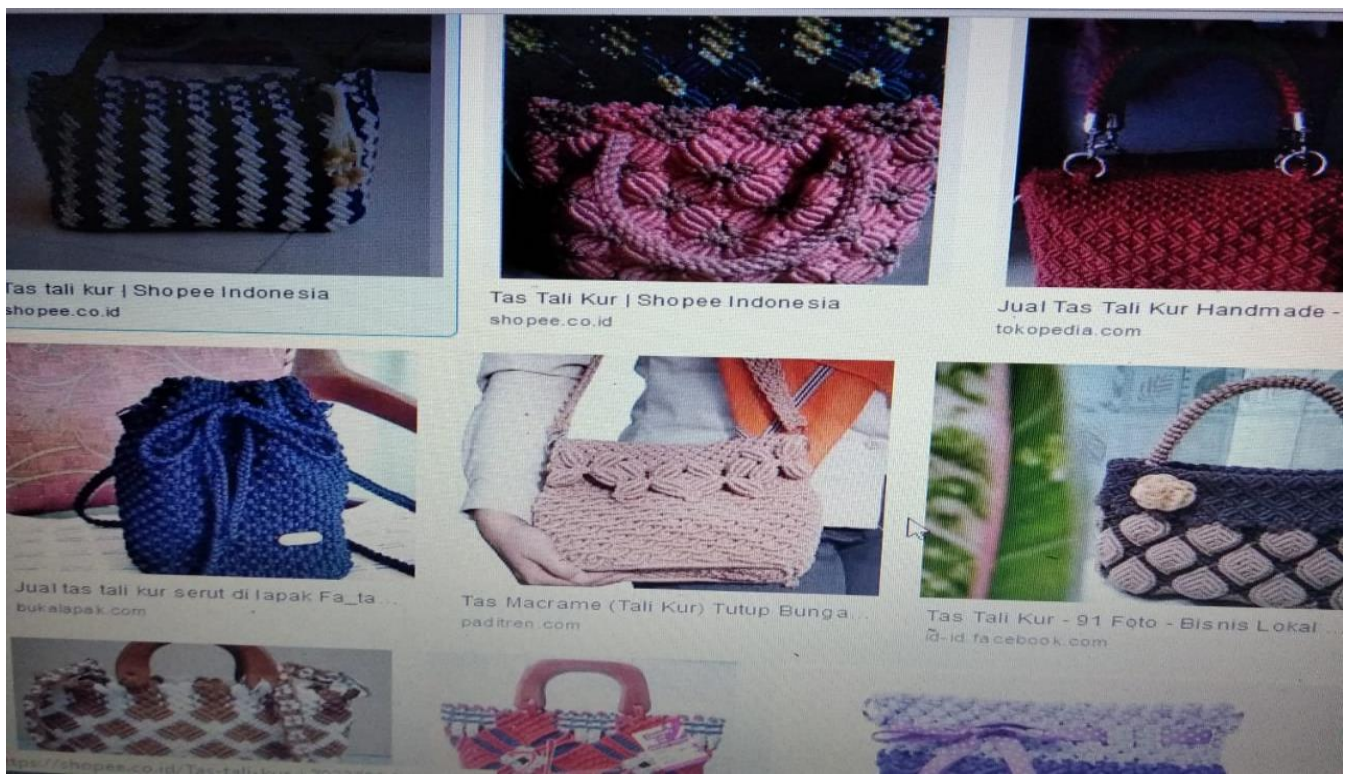

Gambar 1. Dokumentasi/ Contoh Tas Terbuat Dari Tali Kur

\section{Pelaksanaan}

Pelaksanaan IBM yang berjudul Pelatihan Kerajinan Pembuatan Tas dari Tali Kur bagi Ibu Persit Kartika Candra Kirana Kompi Markas 432 Kostrad Kariango Kabupaten Maros. IBM tersebut telah dilaksanakan pada Tanggal 1 September 2019, bertempat di Asrama Kostrad Kariango Kab. Maros. Dalam pelaksanaan IBM tersebut ibuibu persit sangat antusias mengikuti Pelatihan pembuatan tas dari tali kur, berikut beberapa tahap pelaksanaan IBM di kostrad kariango Maros.

a. Kordinasi

IBM ini diawali dengan melakukan kordinasi kepada pimpinan yang membawahi Persit Kartika Candra Kirana yaitu Ibu Danki dari Kompi Markas 432 Kostrad Kariango, kemudian dilanjutkan dengan kordinasi kepada Bamin sebagai TNI yang bekerja sama Ibu Danki dalam mengurus segala kegiatan yang dilaksanakan pada Ibu-Ibu Persit kartika Candra Kirana Kostrad Kariango Maros yang sebelumnya sudah melakukan penandatangan keterangan kesediaan Mitra sebagai bukti menerima kami sebagai IBM di Kostrad Kariango, yaitu melakukan pelatihan pembuatan tas dari tali kur di Kostrad Kariango Kabupaten Maros.

b. Persiapan 
Persiapan yang dimaksud adalah menyediakan segala yang dibutuhkan baik berupa alat/bahan dan kebutuhan lainnya yang dibutuhkan dalam pelaksanaan kegiatan pembuatan tas dari tali kur. Persiapan-persiapan yang dilakukan dalam IbM ini adalah menyediakan tempat pelaksanaan IBM, mendata ibu-ibu Persit Kartika Candra Kirana Kompi Markas 432 Kostrad Kariango yang akan mengikuti pelatihan, menghubungi kesiapan pembimbing dalam pembuatan tas dari tali kur, membeli segala perlengkapan pembuatan Tas dari tali kur, mulai dari tali kur, gunting, korek api, kain pelapis, resleting tas, dll yang dibutuhkan dalam pembuatan tas dari tali kur.

c. Pelaksanaan

Pelaksanaan pelatihan tas dari tali kur di Kostrad Kariango Maros, dilaksanakan pada tanggal 01 september 2019, di mulai dengan pembukaan secara resmi oleh ibu ketua IBM Dr. Amirah Mawardi M.Si, serta penyampaian tujuan umum dan tujuan khusus dari pelaksanaan IBM tersebut, tidak lupa ucapan terima kasih yang tak terhingga kepada ibuibu persit kartika candra kirana atas kesiapan dalam melungkan waktunya untuk mengikuti pelatihan tersebuat.

Dokumentasi pembukaan PKM di kostrad Kariango Maros oleh ibu ketua Dr. Amirah Mawardi, M.Si.

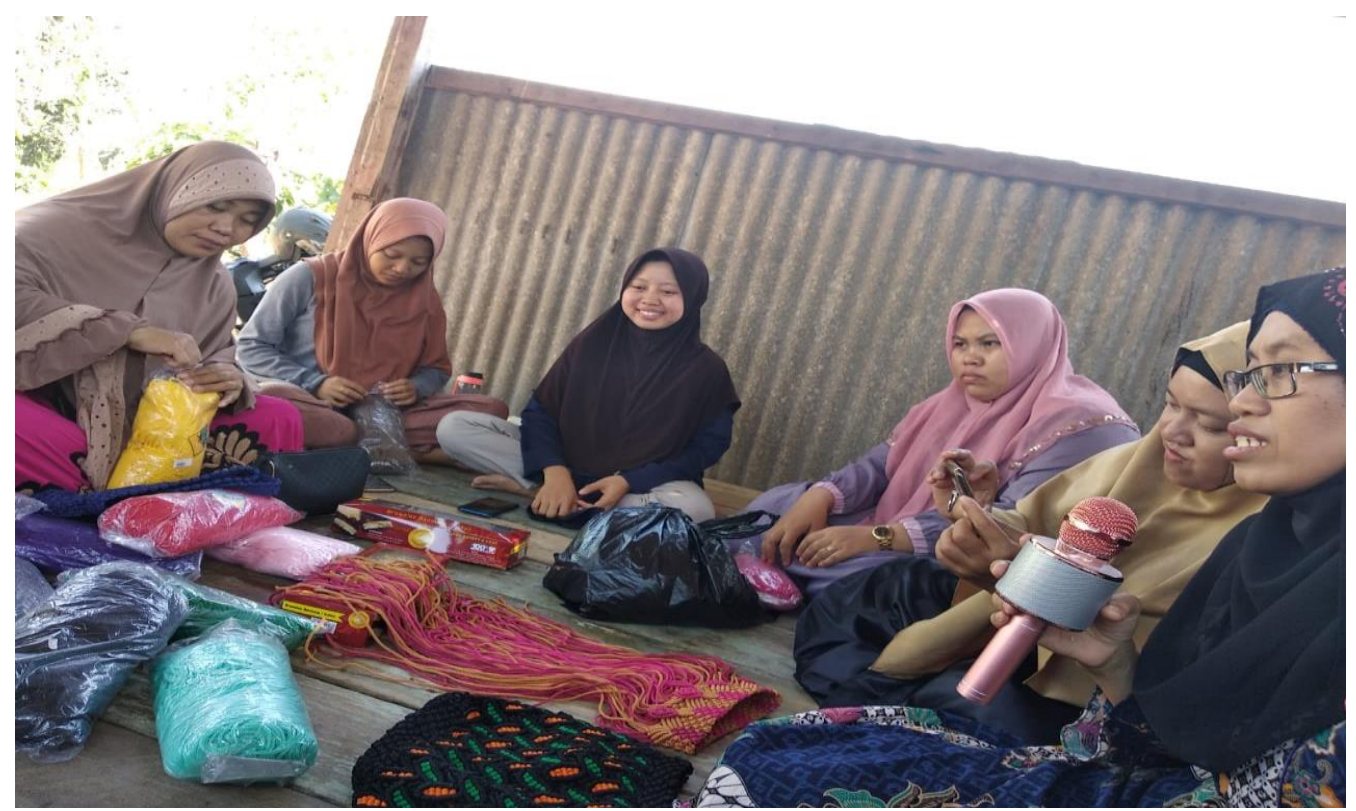




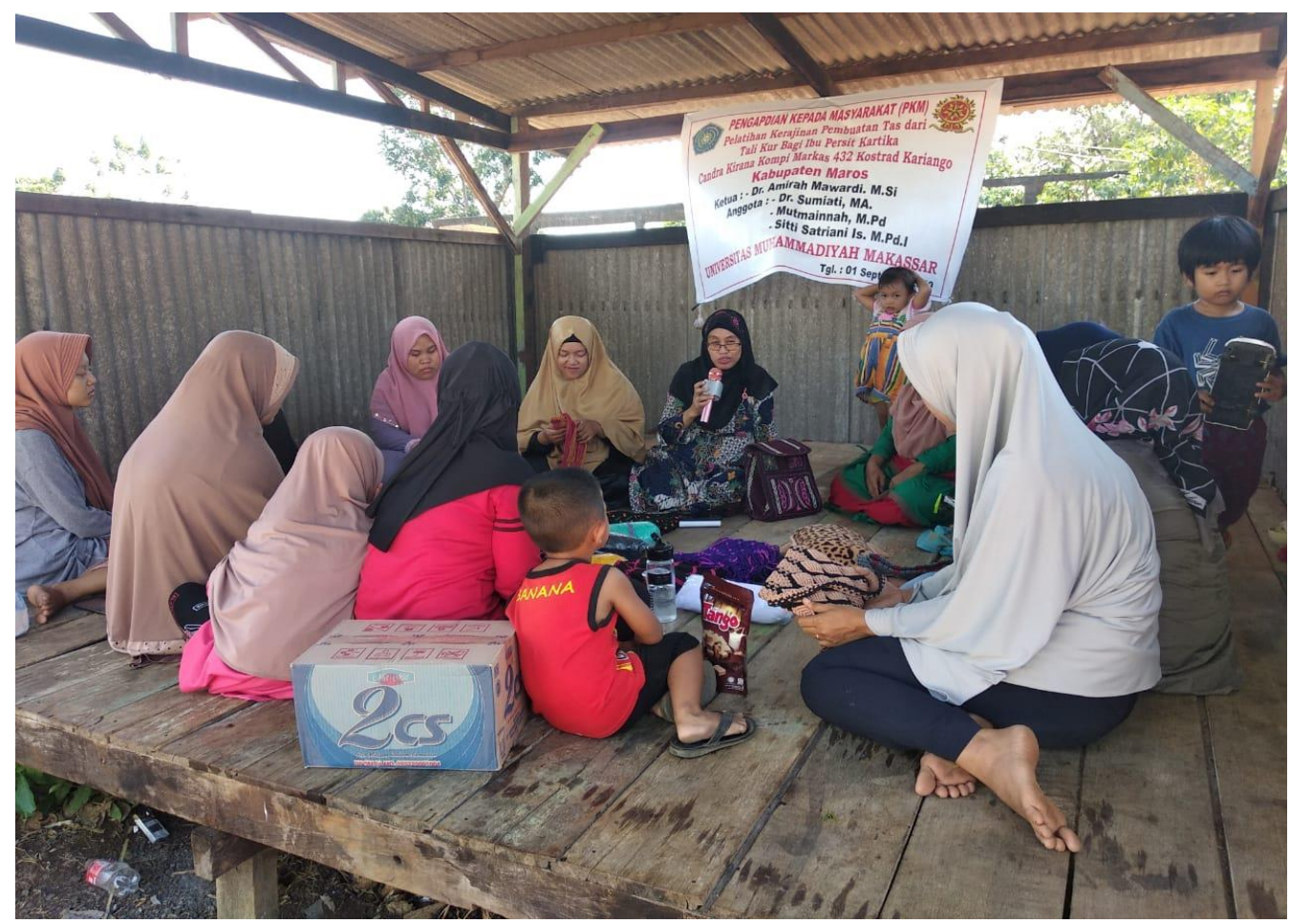

Gambar 2. Dokumentasi Pembukaan PKM

Setelah pembukaan, pelaksanaan pembuatan tas dari tali kur dimulai, dan ibu-ibu persit sangat antusias dan sangat teliti mengikuti intrusi dari pengajar untuk mengait dari tali ketali hingga membentuk sebuah simpul, dari simpul ke simpul tersebuat akan menjadi sebuah tas. Berikut dokumentasi proses pembuatan tas dari tali kur.

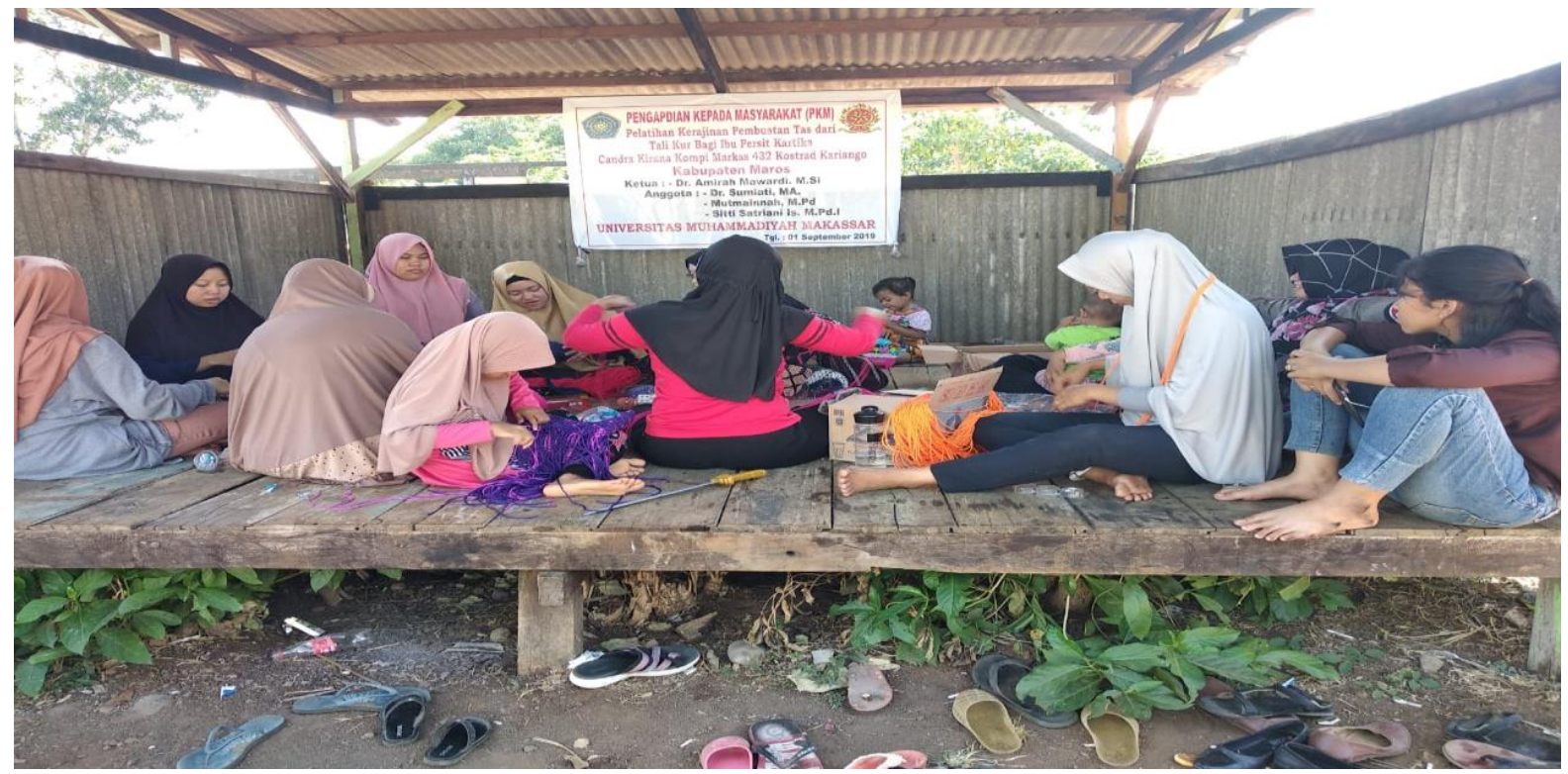

Gambar 3. Proses Pembuatan Tas 
Proses pembuatan tas dari tali kur dimualai dari jam 09 pagi hingga jam 05.30 telah selesai, dengan hasil yang alhamdulillah maksimal, ibu-ibu persit yang mengikuti pelatihan tersebut sudah dapat memuat tas dari tali kur dengan mahir, tentunya tidak terlepas dari bimbingan, arahan dan langsung mencontohkan yang dilakukan ibu pelatih kepada ibu-ibu persit cara mengait tali kur hingga menjadi sebuah tas yang indah dan bisa di jual dengan nilai jual yang tinggi, sebelum penutupan ibu-ibu persit di arahkan untuk menjadikan tas dari tali kur tersebut selain untuk pemakaian pribadi juga untuk di jadikan lahan bisnis dimulai dari home industri atau di pasarkan melalui media sosial seperti Facebook, Watsab maupun media sosial yang lain. Jika hal tersebuat dilakukan maka ibu-ibu persit tidak hanya membuat tas dari tali kur hanya sekedar hobby saja namun bisa menjadi salah satu lahan pengasilan dengan modal sedikit tetapi memiliki nilai jual yang tinggi.

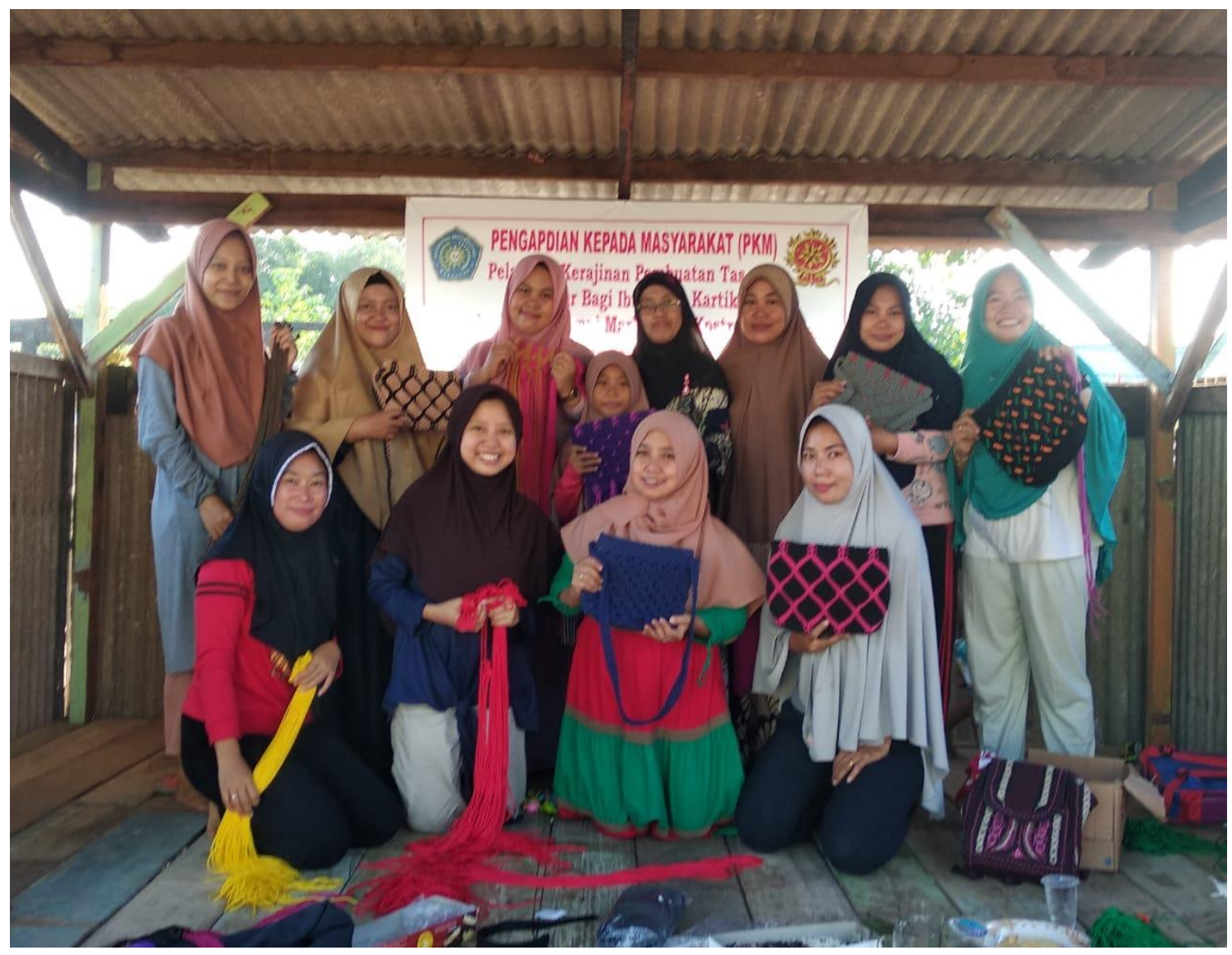

Gambar 5. Dokumentasi Penutupan PKM Bersama Ibu-ibu Persit Kompi Markas 432 Kostrad Kariango Kabupaten Maros. 


\section{E. Kesimpulan}

Pengabdian Kepada Masyarakat telah dilakukan terhadap ibu-ibu Persit Kartika Candra Kirana Kostrad Kariango Maros dari tahap ketahap mulai dari pembuatan proposal, kordinasi, persiapan hingga pelaksanaan hingga penutup, hasil yang diharapkan pada tahap pertama tersebut bahwa ibu-ibu persit sudah mampu mengenal bahan dan alat yang digunakan dalam pembuatan Tas dari tali kur serta mampu membuat Tas dari tali kur.

\section{DAFTAR PUSTAKA}

Hamid, Edy Suandi dan Susilo, Sri.Y. (2011). Strategi Pengembangan Usaha Kecil Dan Menengah di Provinsi Daerah Istimewa Yogyakarta. Jurnal Ekonomi Pembangunan, Vol.12,:44- 55 .

Hardin. (2019). Pembinaan Pengurus Persaudaraan Beladiri Kempo Indonesia (Perkemi) Dojo Sorawolio Dalam Melaksanakan Peran dan Fungsi Manajemen Organisasi. Jurnal Pengabdian Kepada Masyarakat Membangun Negeri Vol. 3 No. 1 April 2019.

Isbandi, (2008). Pemberdayaan, Pengembangan Masyarakat dan Intervensi Komunitas. Jakarta: RajaGrafindo Persada

Soetomo, (2010). Strategi Pembangunan Masyarakat. Yogyakarta: PustakaPelajar

Suharto, Edi. (2005). Membangun Masyarakat, Memberdayakan Rakyat. Bandung: Refika Adinata 